\title{
Political Regimes and FDI Inflows: Empirical Evidence from Upper Middle Income Countries
}

\author{
Seyedashkan Madani* , Mahya Nobakht \\ Department of International Business, Nanjing University of Aeronautics and Astronautics, Nanjing, China \\ *Corresponding author: madanee2012@gmail.com
}

Received March 02, 2014; Revised March 11, 2014; Accepted March 16, 2014

\begin{abstract}
This paper accounts for the political determinant of foreign direct investment (FDI) inflows for 31 Upper-Middle-income Countries (UMCs) over the period of 1990-2011. By measuring the types of regime along an autocracy-democracy spectrum, we empirically investigate how the quality of political institutions in host countries can impact the level of political risks perceived by foreign investors and Multinational Corporates (MNCs). The dynamic panel “difference”' GMM estimator proposed by Arellano and Bond (1991) is developed to deal with autocorrelation problems and endogeneity of the variables in the models. The empirical findings indicate that democracy enhances FDI toward UMCs. Indeed, its positive effect on FDI inflows is remarkable compared to other economic control variables accounted for in this paper.
\end{abstract}

Keywords: FDI inflows, political institutions, democracy, Upper-Middle-income Countries, GMM estimator

Cite This Article: Seyedashkan Madani, and Mahya Nobakht, "Political Regimes and FDI Inflows: Empirical Evidence from Upper Middle Income Countries." Journal of Finance and Economics, vol. 2, no. 3 (2014): 75-82. doi: 10.12691/jfe-2-3-4.

\section{Introduction}

Foreign direct investment (FDI) flows, as one of the manifestations of globalization, have been sharply increasing around the world particularly during the last two decades. By 2010, global FDI peaked at US\$1.4 trillion around 26 times more than its value at the end of 1980. In 2011, foreign affiliates of MNCs [Transnational Corporations] employed an estimated 69 million workers, who generated \$28 trillion in sales and \$7 trillion in value added, some 9 per cent up from 2010 (UNCTAD, 2012). They were also responsible for around three-quarters of the world's commodity trade, and four-fifths of the trade in technology and managerial skills of these economies (Dunning and Lundan, 2008, p.18).

This recent boom in world-wide FDI flows expanded to developing countries in the early 1990s. Indeed, while MNCs in general and FDI inflows as their symbol had widely been deemed as a means by which rich countries exploited the wealth of poor nations during the 1960s and 1970s, the attitudes of elites and policy-makers in developing countries underwent a drastic change during the following decades from this sever pessimistic view to an optimistic perspectives regarding FDI (Kobrin, 1984; Busse, 2004; Hassen and Anis, 2012). Therefore, while the share of developing countries from the global FDI was slim at the beginning of 1990, FDI flows toward developing economies have tremendously increased and reached to US $\$ 680$ billion by 2012, an unprecedented US\$130 billion more than developed countries (UNCTAD, 2012). However, FDI flows are spread unevenly among developing countries. For example, as OECD (2002) reported two-thirds of the total FDI flows originating from OECD countries were embedded only in Asia and Latin America. Within these regions there are strong concentrations points on a few countries, such as China and Singapore in the case of Asia (OECD, 2002, p.7).

Given this gap among developing countries on their performance for attracting FDI, this paper focuses on the political determinant of FDI inflows in Upper Middle income Countries (UMCs). Based on the World Bank (2012) classification, UMCs range between $\$ 4,086$ and $\$ 12,615$ GNI per capita. Classification of developing countries according to their GNI per capita can provide a steady sample of social and political stability aspects. Nevertheless, this classification does not imply the sample has lost its economic variety among countries with more or less the same GNI per capita.

UMCs play a significant role in the world economy and international trade. In 2011, they accounted for $\$ 16.42$ trillion, about a quarter of the world GDP, whereas Lower-Middle-income countries (LMCs) included just $\$ 4.67$ trillion in the same year ${ }^{1}$. In attracting FDI inflows, UMCs also performed much better than other groups of developing countries. In a direct comparison with other developing countries, UMCs alone accounted for almost $70 \%$ of total FDI inflows in developing countries over the course of $2011^{2}$.

Despite this prominent contribution of UMCs to the global economy and international capital flows, to the best of the author's knowledge, the political institutions-FDI

\footnotetext{
${ }^{1}$ See World Development Indicators (WDI) database.

${ }^{2}$ Ibid,
} 
nexus has not been the subject of any available research for UMCs. In fact, while there is a large amount of literature accounting for economic conditions and terms of host countries affecting the business environment of MNCs' activities, recently political risks have been considered as the main barrier for FDI flows towards developing countries. In this regard, scholars examined how the quality of political institutions in host countries can affect the levels of political risks perceived by foreign investors. Nevertheless, the results on the linkage between FDI inflows and the capability of political institutions and regime types, particularly for developing countries, have remained inconclusive in both theories and empirical analyses as well. The lack of conclusive results in literature and previous empirical work motivate this study to examine how political regimes of UMCs are empirically related to FDI inflows.

We employed the dynamic panel model for 31 UMCs as a sample study over the period 1990-2011. The list of countries is available in appendix A. Countries with a population less than one million have been omitted since small countries usually show a particular investment profile (see Schulz, 2009). Countries whose data was not available for the studied period were excluded from the sample as well ${ }^{3}$. China is also dropped from the sample since its foreign investments' profile is deemed idiosyncratic among developing countries (see Fung et al., 2002). In order to measure the political regimes of the sample countries an aggregated index is developed by using two separated "civil liberties" and "political rights" indexes published annually by Freedom House. Arellano and Bond's (1991) “difference”, Generalized Method of Moments (GMM) estimator is applied for the dynamic panel model. This estimator can cope with the endogeneity problem, which was relevant in previous empirical works, and deal with the auto-correlation by adding the lagged dependent variable in the right-hand side of the regression equation.

The next section is a brief review of the literature highlighting the effect of regime types on FDI inflows. Section 3 embeds the methodology of the research for empirical investigations. We construct a panel data analysis for this research, introduce our methodology and argue the reasons behind it in detail. Section 4 presents the empirical results. In this section we also develop a robustness test to check for the consistency of the results. The last section is the conclusion.

\section{Theoretical Background}

According to the Multilateral Investment Guarantee Agency's (MIGA) Political Risk Survey report in 2012, political risks will remain as the single most important constraint for international capital flow into developing countries over the next three years. Since FDI mobility is, actually, an ex-ante by its nature, this kind of risk can appear more serious for multinational firms ( $\mathrm{Li}$ and Resnick 2003; Jensen, 2008, p. 46). Among concerns arising from political risks, government interventions are

\footnotetext{
${ }^{3}$ Lebanon, Cuba, Libya, Serbia, Iraq, Jamaica, Bosnia and Herzegovina, Turkmenistan, Albania and Angola were removed from the sample because of the lack of sufficient data for some variables in the empirical model.
}

ranked as the most serious concern of multinational corporations toward developing countries (see MIGA report, 2010).

As North and Weingast (1989) explained, economic development cannot occur with only changes in regulations or the establishment of the relevant set of rights in a country if its government is not committed to its own decisions and promises. Once a government does not honor its commitments and obligations to the private sectors, increasing uncertainty is raised in the economic atmosphere which in turn leads to a freeze in the business environment. Dishonorable behavior on the part of sovereign states becomes particularly serious when governments are under political pressures from their societies (North and Weingast, 1989; Olson, 1993). In general, politically unstable governments show a more myopic attitude toward foreign assets and properties (Dutta and Roy, 2011; Roe and Siegel, 2007). They may discount future implications more if an expropriation act against MNCs can alleviate a current severe economic hardship (Olson, 1993; Li, 2009).

In this context, the quality of political institutions in host countries can play a significant role in relation to the political risks perceived by foreign firms. Examination of the previous literature identified three different approaches that account for the effect of political institutions and regime type on FDI inflow to the host country.

According to the first approach, in a democracy, institutions and political procedures are fundamentally defined in a way that not only do they foster a business environment for multinationals' activities but also decrease the political risks of foreign investments. To explain these procedures in more detail, scholars point out several advantages and mechanisms involved in democracy including, audience and reputation costs (Jensen, 2008, p. 9, 81; Harms and Ursprung, 2002; Jensen and Schmith, 2005), checks and balances (Olson, 1993; Weingast, 1995; North and Weingast, 1989), large number of veto players (Tsebelis, 1999; Keefer and Stasavage, 2003), and transparency (see Straub, 2008) which leads to better credibility of democratic governments in their commitments toward foreign firms.

Under representative democracy, foreign firms may donate their financial support in an election to the candidates who supports the liberation of policies and advocates more market-friendly policies in favor of foreign investments. The audience costs for leaders, who are identified for their hostile policies regarding foreign firms and international capital, can turn soliciting campaign contributions into a daunting political challenge; since under such conditions they will lose the financial support of multinationals (Hansen and Mitchell, 2000; Hillman and Ursprung, 1988).

When survival was at stake, the sovereign would heavily discount the future, making the one-time gain of reneging more attractive relative to the future opportunities forgone (North and Weingast, 1989). Under such conditions, audience costs may not uphold credibility for a state alone. Indeed, the most effective way to counter high levels of the credibility of a state is to define political institutions so that a government is unable to easily change policies and conditions in terms of foreign investments and multinationals' activities. Scholars point 
out the role of veto players ${ }^{4}$ in this context. The most significant contribution of veto players on FDI occurs via stabilizing both political and economic policies in a country (see Choi and Samy, 2008). This enables multinationals to more precisely predict initial costs and the rate of return on investment in ex ante (see Jensen, 2003).

Furthermore, the lack of transparency can have a detrimental effect on MNCs if the host government tries to hide the truth about important economic factors of the country (See Rosendorff and Shin, 2012). Meanwhile, widespread bureaucratic and political corruption can increase the initial cost of investments for MNCs (Wei, 2000; Mauro, 1995). The transparency effect is more clarified in democracies (Jensen, 2003 and 2008). They encompass a large veto players and different independent political institutions which enables each of them to monitor one another. As the number of veto players in government increases, their ability to collude on accepting bribes decreases (Andrews and Montinola, 2004). A number of empirical researches also show domestic political institutions in democracies can provide a favorable business environment for foreign investments. Busse (2004), Harms and Ursprung (2002), Jensen (2003, and 2008), Asidue and Lien (2011) and Adam and Filippaios (2007) all indicated democracy can enhance FDI flows in host countries.

On the other side of the debate, conventional wisdom holds that MNCs have a cozy relationship with dictatorships. In authoritarian regimes leaders and governments can offer generous fiscal and financial incentives to multinational firms regardless of political pressures or criticisms from political rivals (see Alesina and Dollar, 2000). These regimes can firmly adopt and implement new market-friendly policies for attracting FDI even when a significant part of domestic actors are in opposition with these policies. This flexibility in policies of an autocratic system makes it able to respond to volatility in the macroeconomic environment in a timely manner which in turn increases its attractiveness for foreign investors. In contrast, as Mathur and Singh (2013) argued, democracies may be associated with a lower level of FDI inflows; since, in the presence of large number of veto players with divergent preferences, democratic institutions are often unable to pass new legislations complying with foreign investors' desires. Meanwhile, a secure autocrat who is expecting long-run tenure can fulfill the security of property rights and contract enforcement that generates economic growth (Olson, 1993; Gehlbach and Keefer, 2011). Some empirical investigations also prove the affinity between autocracies and FDI inflows. Oneal (1994), Li and Resnick (2003), Gehlbach and Keefer (2011), and Resnick (2001) found autocracies more conducive for MNCs activities, based on their own empirical results.

Ultimately, some authors find no clear implication on the linkage between FDI and political regimes. In this light, they argue that the political risks can be high in both democracies and autocracies if politicians are sufficiently motivated. Li (2009) argues high "executive turnover"

\footnotetext{
${ }^{4}$ Veto players are individual or collective actors whose agreement (by majority rule for collective actors) is required for a change of the status quo (Tsebelis, 1995).
}

along with short "leader tenure to date" can increase political insecurities around leaders and give them a short time horizon on their performances. These, in turn, can provide the political capacity for leaders in both democracy and autocracy to enact an expropriation against MNCs in a host country. Schulz (2009) argues that the relationship between FDI and democracies are different if one analyzes FDI based on industry-level. According to his results, democracy facilitates FDI inflows in the manufacturing sector but no meaningful relationship exists between democracy and FDI in the primary and service sectors.

Regarding to above theories and approaches, we propose three optimistic, pessimistic and neutral hypotheses on the linkage between democracy and FDI inflows for UMCs as follows:

Hypotheses 1: multinational firms prefer to invest in democracies since a democratic regime benefits from some inner mechanisms which make it more credible and reliable in its commitments toward foreign investors compared to its alternatives. And therefore, democratic regimes are associated with a higher level of FDI toward host countries.

Hypotheses 2: democratic institutions deter foreign investors because they adopt policies which are deleterious for MNCs' operation. Instead, dictatorships are found to be more credible since leaders are better authorized to offer generous fiscal and financial incentives to multinationals.

Hypotheses 3: there is no evidence that links a particular type of regime to FDI inflows to host country since both type of regimes have a long historical background of confiscating foreign assets.

In the following sections of this study, we will empirically explore the role of regime types for attracting FDI and examine which hypothesis is more plausible for UMCs in practice.

\section{Data Description}

Empirical analysis of this study includes thirty-one UMCs from 1990 to 2011. These countries exhibit variation in the level of FDI flows and regime types over time and across countries which in turn make them appropriate for a discriminating statistical assessment. The dependent variable is measured by net FDI inflows per capita. Using this proxy as the independent variable clarifies the position of each country in the sample on its foreign investment profile compared to the others. Data for net FDI inflows are obtained from the UNCTAD statistics database (2013).

\subsection{Political Regimes}

This study utilizes Freedom House data to measure the types of regime across countries in the sample. Data has been published regularly in annual reports on the evaluation of freedom in the world since 1972. By combining analytical reports and numerical ratings, Freedom House divides countries into two broad categories: "Civil liberties", and "Political rights", Each country is scaled between 1 and 7 for both the civil 
liberties index and the political rights index where 1 refers to the most free and 7 denotes the least free ${ }^{5}$. Data on both these two indicators are combined together to encompass the single aggregated level of the Freedom (free) index. In this regard, we similarly follow Busse's (2004) transformation formula presented below.

$$
\begin{aligned}
& \text { free }(\text { aggregated index }) \\
& =\left(\frac{14-(\text { political rights }+ \text { civil rights })}{12}\right) * 10
\end{aligned}
$$

We use this aggregated index to distinguish between countries of democracy and autocracy where the free index is calculated between 0 (no political rights and civil liberties) and 10 (complete set of political rights and civil liberties) scores. The higher the score means the higher the level of democracy in the country.

\subsection{Control Variables}

To improve the explanatory power of the model and at the same time to decrease possibilities of omitted variable problems, the most relevant economic variables of FDI are considered in the model. In this regard, we account for market size, openness to trade, economic growth and inflation rate in our model. According to the literature, market size, openness and economic growth are expected to have positive effects on FDI inflows to host countries while the expected sign of inflation is negative (see Table 1 in appendix B for definitions and data sources).

\section{Methodology and Research}

We specify a dynamic panel model and apply the "difference" GMM estimator introduced by Arellano and Bond (1991). Panel data structure allows controlling for unobserved heterogeneities among individuals, increasing the degree of freedom, mitigating multi-collinearity and removing omitted variable bias in the models (Hisao, 2007; Hisao, 2005). A dynamic approach can also deal with auto-correlation in the model (Keele and Kelly, 2005; Busse and Hefeker, 2007). Endogeneity is one of the main obstacles in the previous empirical studies. Therefore, in order to reach a consistent and efficient estimation of the coefficients in the model of this study, the Generalized Method of Moments (GMM) estimator is used for the dynamic panel model. The GMM estimator can control for the endogeneity of explanatory variables by defining instruments for them to obtain a consistent estimation. We follow the difference GMM estimator since it defines internal instruments built from past observations of the instrumented variables (see Roodman, 2006). As Arellano and Bond (1991) suggested first difference of variables can eliminate the country specific effects of the model.

Similar to previous empirical literature on the determinants of FDI inflows, the double-log specification is conducted for this study as well. The final specification of model can be written as follows:

\footnotetext{
${ }^{5}$ Freedom House has classified countries based on their obtained scores in political rights and civil liberties indexes so that countries which have combined average ratings for these two indexes between 1 to 2.5 are designated as "Free", between 3.0 and 5.5 as "Partly Free," and between 5.5 and 7.0 as "Not Free."
}

$$
\begin{aligned}
\Delta L F D I_{i t}= & \beta_{1} \Delta L F D I_{i, t-1}+\beta_{2} \Delta \text { Lfree }_{i t} \\
& +\beta_{3} \Delta \text { Linfr }_{i t}+\beta_{4} \Delta \text { Lecost }_{i t} \\
& +\beta_{5} \Delta \text { Lopen }_{i t}+\beta_{6} \Delta \text { Lmark }_{i t}+\Delta \varepsilon_{i t}
\end{aligned}
$$

Where, FDI is net FDI inflows per capita. free accounts for the level of democracy based on Eq. (1). We also control for a range of economic variables of FDI including openness to trade (open), inflation rate (infr), economic growth (ecost), and market size (mark) in the model.

In order to use internal instruments for our empirical model, this study follows Roodman's (2006) instructions for defining valid instruments on the difference GMM. In this regard, we include all available lags of endogenous variables in level as instruments. Due to the predetermined $y_{i, t-1}$, the $y_{i, t-2}$ and deeper lags are included in the model as instrument for lagged difference dependent variable. Using this method requires the assumption that explanatory variables are weakly exogenous, since it paves the way for the use of internal instruments. All other explanatory variables are treated as strictly exogenous. As a strictly exogenous variable can be instrumented by itself; thus, the first difference of them is applied as standard instruments.

Moreover, we utilize the two-step GMM estimator since it is robust to heteroskedasticity and also asymptotically efficient. In order to reach consistence GMM estimation, the validity of instruments and the assumption for the error term is a crucial part of the estimation procedure. Thus, the Sargan test of overidentifying restrictions is applied to check the overall validity of the instruments by analyzing the sample analog of the moment conditions used in the estimation procedure. The Arellano and Bond (AB) second serial correlation test is the second typical standard test after GMM estimation since the lack of serial correlation in the error terms is necessary for a consistence estimation of variables.

In the following, we will first examine the stationary of the variables using different approaches on the unit root test for panel data. To avoid spurious regression caused by non-stationary variables in empirical estimations, we will employ four common methods to test the stationary of our variables. In this regard, the Levin, Lin, and Chu (LLC), the Im, Pesaran, and Shin (IPS), and Fisher-ADF and Fisher-PP tests are run in the next section. We also examine the conditions on unobserved-country specific time-invariant effects to investigate the nature of these effects in our model; since the random or fixed effects can be interpreted in different econometric specifications. The Hausman test is therefore implemented to check for the random or fixed effects of country specific effects.

\section{Empirical Results}

In this section, the results of the unit root tests, the Husman test and the difference GMM estimation are presented and analyzed. The results of the unit root test showed all the variables were stationary at level except market size (Lmark) (refer to Table 2 in Appendix B); thus, the tests were repeated for all variables at first difference. The results are reported in Table 3 . Unlike the results at level, all variables are now stationary at first difference since the null hypothesis is rejected at $1 \%$ level of significance. 
Table 3. Panel Unit Root Tests Results at first difference

\begin{tabular}{ccccccccc} 
Variable & \multicolumn{8}{c}{ Intercept } \\
LFDI & LLC & & IPS & \multicolumn{3}{c}{ ADF-Fisher } & \multicolumn{2}{c}{ PP-Fisher } \\
Lfree & -18.18 & $*$ & -16.53 & $*$ & 405.49 & $*$ & 738.85 & $*$ \\
Lopen & -2.160 & $*$ & -7.850 & $*$ & 91.518 & $*$ & 140.31 & $*$ \\
Linfr & -14.13 & $*$ & -14.96 & $*$ & 324.15 & $*$ & 790.68 & $*$ \\
Lmark & -11.29 & $*$ & -8.466 & $*$ & 207.00 & $*$ & 225.16 & $*$ \\
Lecost & -25.77 & $*$ & -23.56 & $*$ & 518.16 & $*$ & 1668.5 & $*$ \\
\hline & \multicolumn{1}{c}{ Intercept and Trend } & & & \\
\hline & LLC & & IPS & & ADF-Fisher & PP-Fisher \\
LFDI & -12.67 & $*$ & -14.44 & $*$ & 313.07 & $*$ & 595.28 & $*$ \\
Lfree & -9.356 & $*$ & -14.36 & $*$ & 232.75 & $*$ & 267.43 & $*$ \\
Lopen & -15.32 & $*$ & -15.97 & $*$ & 320.39 & $*$ & 439.88 & $*$ \\
Linfr & -12.44 & $*$ & -12.27 & $*$ & 253.60 & $*$ & 968.59 & $*$ \\
Lmark & -13.23 & $*$ & -9.208 & $*$ & 196.09 & $*$ & 274.23 & $*$ \\
Lecost & -20.77 & $*$ & -19.75 & $*$ & 396.77 & $*$ & 1375.5 & $*$ \\
\hline
\end{tabular}

* significant at $1 \%$ - rejection of the null hypothesis denotes the panel series does not have a unit root

the values in front of each variable are t-statistic

The maximum lag length selection based on automatic Schwarz

Information criterion

Table 4 presented the result of the Husman test for the six explanatory variables included in this study. The large chi-square statistic of the test result suggests Random Effects (RE) estimators are not suitable for this study; instead, Fixed Effects (FE) estimation is preferred for the model.

Table 4. Hausman Test

\begin{tabular}{cccc}
\multicolumn{5}{c}{ Table 4. Hausman Test } \\
\hline Test Summary & Chi-Sq. Statistic & Chi-Sq. d.f. & Prob. \\
\hline Cross-section random & 53.2266 & 5 & 0.0000
\end{tabular}

The empirical evidence on the relation of regime types and FDI inflows are presented in Table 5 and Table 6. By using Arellano and Bond's (1991) difference GMM and Arellano and Bover's (1995) orthogonal GMM for 31 UMCs during 1990 to 2011, we develop 4 separated specifications in order to assess the reliability of the findings on the economic control variables and to explore the correlation between regime types and FDI inflows. Model (1) is the baseline model and includes the logarithm of inflation rate (Linflr), market size (Lmark), Openness to trade (Lopen), economic growth (Lecost) and Lagged of dependent variable (LFDI (-1)). Keeping these variables unchanged, the logarithm of political regime (Lfree) is introduced in model (2). In model (3) the baseline model is re-estimated by the orthogonal GMM estimator. Similarly in the last specification, the interested explanatory variable ( $L$ free) is estimated by the orthogonal GMM to check for consistency of the results in the model (2).

Model (1) in Table 5 tested the contribution of control variables involved in Eq. (2). The most of results are in agreement with the theories about the economic determinants of FDI. Based on the results, the lag of FDI had a significant and positive effect on the current FDI inflows. This confirms the assertion that previous records of a country's investment profile can have a direct effect on foreign investors' decision for this year. Economic growth and market size were also positively significant at $1 \%$. A high rate of economic growth can assure multinationals on the prosperity of their investments in the host country's market. A large market size also provides efficient utilization of resources and exploitation of economies of scale for MNCs' operation in a host country. The sign for inflation was also in line with theories but was insignificant. A high inflation rate conveys a message about high levels of economic instability in a host country which is deleterious for long-run foreign investment. The only unexpected result belongs to openness to trade whose sign is in contrast with theory in the model. Openness' contribution on FDI inflows was negative and statistically significant in the model (1). One explanation for the negative effect of openness can be argued by the "tariff jumping" theory. According to this theory, multinationals prefer a horizontal investment strategy as an entrance mode to host countries, characterized by high tariff rates and barriers on trade, in order to serve these foreign markets directly by setting up the entire production lines in those countries. The hypothesized link between FDI and trade protection is seen as fairly clear by most trade economists-higher trade protection should make firms more likely to substitute affiliate production for exports to avoid the costs of trade production (Blonigen, 2005). Therefore, imposing more restrictions on trade can make it difficult for foreign firms to target domestic markets of a host country through exporting goods and services; but, instead, can bring more protection for MNCs' subsidiaries in that country.

Table 5. results for the effect of political regime on FDI

\begin{tabular}{|c|c|c|}
\hline Variable & Model (1) & Model (2) \\
\hline LFDI(-1) & $\begin{array}{l}0.1266^{* * *} \\
(0.0000)\end{array}$ & $\begin{array}{l}0.4096 * * * \\
(0.0000)\end{array}$ \\
\hline Lfree ${ }^{a}$ & & $\begin{array}{l}0.680230 \text { ** } \\
(0.0158)\end{array}$ \\
\hline Linfr & $\begin{array}{l}-0.0032 \\
(0.8948)\end{array}$ & $\begin{array}{l}-0.0743^{*} \\
(0.0808)\end{array}$ \\
\hline Lopen & $\begin{array}{l}-0.7746 * * * \\
(0.0045)\end{array}$ & $\begin{array}{l}-0.0245 \\
(0.9590)\end{array}$ \\
\hline Lmark & $\begin{array}{l}1.8162^{* * *} \\
(0.0000)\end{array}$ & $\begin{array}{l}1.6143^{* * *} \\
(0.0000)\end{array}$ \\
\hline Lecost & $\begin{array}{l}0.1245^{* * *} \\
(0.0000)\end{array}$ & $\begin{array}{l}0.1198^{* * *} \\
(0.0000)\end{array}$ \\
\hline Number of countries, $n$ & 31 & 31 \\
\hline Number of observations & 609 & 609 \\
\hline instrument rank ${ }^{\mathrm{b}}$ & 31 & 31 \\
\hline sargan chi-square ${ }^{c}$ & 0.4692 & 0.6478 \\
\hline$A B$ test (p-value) ${ }^{d}$ & 0.1102 & 0.6888 \\
\hline
\end{tabular}

\section{Notes:}

There are p-values in parenthesis: $* * * \mathrm{P}<0.01, * * \mathrm{p}<0.05, * \mathrm{p}<0.10$.

${ }^{\mathrm{a}}$ free is $\log$ of the aggregated freedom house index calculated based on Eq. (1). A higher number implies more democracy.

${ }^{b}$ instrument rank is the instrument matrix which is equal to number of instruments.

${ }^{\mathrm{c}}$ Under the null hypothesis the instruments used are not correlated with the residuals.

${ }^{d}$ the null hypothesis is that the errors in first difference is no second serial correlation.

In the regression model (2) of Table 5, the final effect of political regimes on FDI inflows becomes strongly positive and significant at 5\% supporting the first hypothesis of this study which supposed a supportive effect in democracies for FDI inflows. Indeed, the results show after market size' impact, the influence of regime type variable (free) is identified as the second most important factor in the model (2). If a country moves toward more democracy by only a one percent change in the free index, FDI inflows increase 0.68 in per capita, ceteris paribus. The control variables also kept their signs but this time Linflr becomes significant at $10 \%$ while Lopen loses its statistical significance.

\subsection{Robustness Tests}


To investigate the robustness of the obtained results, we develop a sensitivity analysis in the second part of empirical section. In this light, we employ the second common transformation called orthogonal deviation GMM, proposed by Arellano and Bover (1995), in order to check the consistency of the results.

One weakness of the difference GMM estimator is that it may implement poorly in unbalanced panel data where some observations for variables are missed across countries and over time. Since in the orthogonal deviation method the contemporaneous observations are subtracted from the average of all future observations which are in hand, orthogonal deviation transforms can be used as an influential method to preserve the sample size of studies with unbalanced panel structures. The lags of variables in level have still remain as valid instruments for endogenous variables transformed in orthogonal deviation since the lagged observation do not enter the formula.

In Table 6 the results of orthogonal GMM for the baseline model and the model with the free (the aggregated index) variable are presented in models (3) and (4), respectively. The significance of the variables is, in general, improved over both models using this transformation method. The results on Linflr, Lecost, and mark are in compliance with those reported in models (1) and (2). Lopen was again negative over the last two specifications but only significant at $10 \%$ confidence. These results imply the mixed and complicated impact of openness on different types of FDI in developing country. Since the highest share of FDI took place in the service sector (see UNCTAD, 2012), the negative effects of openness can be reasonable based on the above explanation. The sign of political regime variable (free) in model (4) confirms the positive role of democracy on FDI inflows towards UMCs as well. Namely, the regimes which are freer, received more points on civil liberties and political rights can also attract more FDI inflows compared with autocracies.

Table 6. Robustness test

\begin{tabular}{|c|c|c|}
\hline \multicolumn{3}{|c|}{ Orthogonal deviation GMM, Dynamic panel data analysis } \\
\hline Variable & Model (3) & Model (4) \\
\hline \multirow[t]{2}{*}{ LFDI $(-1)$} & $0.3982 * * *$ & $0.4892 * * *$ \\
\hline & $(0.0000)$ & $(0.0000)$ \\
\hline \multirow[t]{2}{*}{$L_{\text {free }}^{a}$} & & $0.3765 * * *$ \\
\hline & & $(0.0002)$ \\
\hline \multirow[t]{2}{*}{ Linfr } & $-0.1051^{* * *}$ & $-0.0888 * * *$ \\
\hline & $(0.0033)$ & $(0.0000)$ \\
\hline \multirow[t]{2}{*}{ Lopen } & $-0.2569 *$ & $-0.3032 *$ \\
\hline & $(0.0539)$ & $(0.0513)$ \\
\hline \multirow[t]{2}{*}{ Lmark } & $1.4303 * * *$ & $1.1101^{* * *}$ \\
\hline & $(0.0000)$ & $(0.0000)$ \\
\hline \multirow[t]{2}{*}{ Lecost } & $0.1616 * * *$ & $0.1504 * * *$ \\
\hline & $(0.0000)$ & $(0.0000)$ \\
\hline Number of countries, $\mathrm{n}$ & 31 & 31 \\
\hline Number of observations & 609 & 609 \\
\hline instrument rank ${ }^{\mathrm{b}}$ & 31 & 31 \\
\hline sargan chi-square ${ }^{c}$ & 0.4342 & 0.2841 \\
\hline AB test (p-value $)^{d}$ & 0.2405 & 0.6888 \\
\hline
\end{tabular}

Notes:

There are $\mathrm{p}$-values in parenthesis: ${ }^{* * *} \mathrm{P}<0.01$, ** $\mathrm{p}<0.05$, ${ }^{*} \mathrm{p}<0.10$.

${ }^{\mathrm{a}}$ free is log of the aggregated freedom house index calculated based on

Eq. (1). A higher number implies more democracy.

${ }^{\mathrm{b}}$ instrument rank is the instrument matrix which is equal to number of instruments.

${ }^{\mathrm{c}}$ Under the null hypothesis the instruments used are not correlated with the residuals.

d the null hypothesis is that the errors in first difference is no second serial correlation.

\section{Conclusion}

This paper examines empirically how political regimes are related to FDI in UMCs over the period of 1990-2011. Previous empirical studies have commonly been confronted with two main limitations. First, most of these previous studies do not distinguish between developed and developing countries as a sample for the panel studies; yet, as Blonigen and Wang (2004) caution, pooling both poor and wealthy countries as a sample in empirical FDI determinants study is inappropriate. Using UMCs as a sample for the empirical investigation of political determinant of FDI will fill this gap; since these countries are ranged from $\$ 4,086$ - $\$ 12,615$ GNI per capita which leads them to be more similar to each other in social conditions. Second, most empirical studies on the determinants of FDI do not control for the endogeneity existing among explanatory variables. Therefore, Difference GMM and Orthogonal GMM are used to control for the endogeneity among the variables and to preserve the size of the sample, respectively.

Based on the results, democratic systems are more favorable to foreign direct investment (FDI) in UMCs. This evidence supports the first hypothesis of this study in which democracy associates with higher level of FDI inflows to host countries by decreasing political risks of FDI. Our findings are robust across empirical models. Democracy can induce FDI inflows much more than most of the other economic control variables, ceteris paribus.

This study empirically proves the importance of the quality of political institutions in recipient countries particularly for UMCs. This result is important as most current UMCs' FDI promotion policies are confined to only economic sectors of these economies, while the importance of political institution reforms, in the most conservative view, is equal to other economic factors of FDI inflows.

\section{References}

[1] Adam, Antonis, and Fragkiskos Filippaios. "Foreign direct investment and civil liberties: A new perspective." European Journal of Political Economy 23, no. 4 (2007): 1038-1052.

[2] Alesina, Alberto, and David Dollar. "Who gives foreign aid to whom and why?." Journal of economic growth 5, no. 1 (2000): 3363.

[3] Andrews, Josephine T., and Gabriella R. Montinola. "Veto players and the rule of law in emerging democracies." Comparative Political Studies 37, no. 1 (2004): 55-87.

[4] Arellano, Manuel, and Olympia Bover. "Another look at the instrumental variable estimation of error-components models." Journal of econometrics 68, no. 1 (1995): 29-51.

[5] Arellano, Manuel, and Stephen Bond. "Some tests of specification for panel data: Monte Carlo evidence and an application to employment equations." The Review of Economic Studies 58, no. 2 (1991): 277-297.

[6] Asiedu, Elizabeth, and Donald Lien. "Democracy, foreign direct investment and natural resources." Journal of International Economics 84, no. 1 (2011): 99-111.

[7] Blonigen, Bruce A. "A review of the empirical literature on FDI determinants." Atlantic Economic Journal 33, no. 4 (2005): 383403.

[8] Blonigen, Bruce A., and Miao Wang. Inappropriate pooling of wealthy and poor countries in empirical FDI studies. No. w10378. National Bureau of Economic Research, 2004.

[9] Busse, Matthias, and Carsten Hefeker. "Political risk, institutions and foreign direct investment." European Journal of Political Economy 23, no. 2 (2007): 397-415. 
[10] Busse, Matthias. "Transnational corporations and repression of political rights and civil liberties: An empirical analysis." Kyklos 57, no. 1 (2004): 45-65.

[11] Cheng, Leonard K., and Yum K. Kwan. "What are the determinants of the location of foreign direct investment? The Chinese experience." Journal of international economics 51, no. 2 (2000): 379-400.

[12] Choi, Seung-Whan, and Yiagadeesen Samy. "Reexamining the effect of democratic institutions on inflows of foreign direct investment in developing countries." Foreign Policy Analysis 4.1 (2008): 83-103.

[13] Dunning, John H., and Sarianna M. Lundan. Multinational enterprises and the global economy. Edward Elgar Publishing, 2008.

[14] Dutta, Nabamita, and Sanjukta Roy. "Foreign direct investment, financial development and political risks." The Journal of Developing Areas 44.2 (2011): 303-327.

[15] Fung, Kwok Chiu, Hitomi lizaka, and Stephen Parker. "Determinants of US and Japanese direct investment in China." Journal of Comparative Economics 30.3 (2002): 567-578.

[16] Gehlbach, Scott, and Philip Keefer. "Investment without democracy: ruling-party institutionalization and credible commitment in autocracies." Journal of Comparative Economics 39, no. 2 (2011): 123-139.

[17] Hansen, Wendy L., and Neil J. Mitchell. "Disaggregating and explaining corporate political activity: Domestic and foreign corporations in national politics." American Political Science Review (2000): 891-903.

[18] Harms, Philipp, and Heinrich W. Ursprung. "Do civil and political repression really boost foreign direct investments?." Economic Inquiry 40, no. 4 (2002): 651-663.

[19] Hassen, Soltani, and Ochi Anis. "Foreign Direct Investment (FDI) and Economic Growth: an approach in terms of cointegration for the case of Tunisia." Journal of Applied Finance \& Banking 2.4 (2012): 193-207.

[20] Hillman, Arye L., and Heinrich W. Ursprung. "Domestic politics, foreign interests, and international trade policy." The American Economic Review (1988): 729-745.

[21] Hsiao, Cheng. "Panel data analysis_advantages and challenges." Test 16, no. 1 (2007): 1-22.

[22] Hsiao, Cheng. "Why panel data?." The Singapore Economic Review 50, no. 02 (2005): 143-154.

[23] Jensen, Nathan M. "Democratic governance and multinational corporations: Political regimes and inflows of foreign direct investment." International Organization 57.3 (2003): 587-616.

[24] Jensen, Nathan M. Nation-states and the multinational corporation: A political economy of foreign direct investment. Princeton University Press, 2008.

[25] Jensen, Nathan M., and Scott Schmith. "Market Responses to Politics The Rise of Lula and the Decline of the Brazilian Stock Market." Comparative Political Studies 38, no. 10 (2005): 12451270.

[26] Jensen, Nathan. "Political risk, democratic institutions, and foreign direct investment." Journal of Politics 70, no. 4 (2008): 1040-1052.

[27] Keefer, Philip, and David Stasavage. "The limits of delegation: Veto players, central bank independence, and the credibility of monetary policy." American political science review 97, no. 3 (2003): 407-423.

[28] Keele, Luke, and Nathan J. Kelly. "Dynamic models for dynamic theories: The ins and outs of lagged dependent variables." Political Analysis 14, no. 2 (2006): 186-205.

[29] Kobrin, Stephen J. "Expropriation as an attempt to control foreign firms in LDCs: trends from 1960 to 1979." International Studies Quarterly (1984): 329-348.

[30] Li, Quan, and Adam Resnick. "Reversal of fortunes: Democratic institutions and foreign direct investment inflows to developing countries." International organization 57, no. 1 (2003): 175-212.

[31] Li, Quan. "Democracy, autocracy, and expropriation of foreign direct investment." Comparative Political Studies 42, no. 8 (2009): 1098-1127.

[32] Mathur, Aparna, and Kartikeya Singh. "Foreign direct investment, corruption and democracy." Applied Economics 45, no. 8 (2013): 991-1002.

[33] Mauro, Paolo. "Corruption and growth." The quarterly journal of economics 110.3 (1995): 681-712.

[34] North, Douglass C., and Barry R. Weingast. "Constitutions and commitment: the evolution of institutions governing public choice in seventeenth-century England." The journal of economic history 49, no. 04 (1989): 803-832.

[35] Olson, Mancur. "Dictatorship, democracy, and development." American Political Science Review (1993): 567-576.

[36] Oneal, John R. "The affinity of foreign investors for authoritarian regimes." Political Research Quarterly 47, no. 3 (1994): 565-588.

[37] Organisation for Economic Co-operation and Development. Foreign direct investment for development: Maximising benefits, minimising costs. OECD Publishing, 2002.

[38] Roe, Mark J., and Jordan I. Siegel. "Political instability and financial development." Unpublished Manuscript, Harvard Law School (2007).

[39] Roodman, David. "How to do xtabond2: An introduction to difference and system GMM in Stata." Center for Global Development working paper 103 (2006).

[40] Rosendorff, B. Peter, and Kongjoo Shin. "Importing Transparency: The Political Economy of BITs and FDI Flows." Manuscript, New York University Political Science Department. New York, NY: NYU. Available at: https://files. nyu. edu/bpr1/public/papers/RosendorffShinAPSA2012. pdf (2012).

[41] Schulz, Heiner. "Political Institutions and Foreign Direct Investment in Developing Countries: Does the Sector Matter?." Available at SSRN 1403983 (2009).

[42] Straub, Stephane. "Opportunism, corruption and the multinational firm's mode of entry." Journal of International Economics 74, no. 2 (2008): 245-263.

[43] Tsebelis, George. "Veto players and law production in parliamentary democracies: An empirical analysis." American Political Science Review (1999): 591-608.

[44] UNCTAD, Geneva. "World investment report: Towards a New Generation of Investment Policies." (2012)

[45] Wei, Shang-Jin. "How taxing is corruption on international investors?." Review of economics and statistics 82.1 (2000): 1-11.

[46] Weingast, Barry R. "Economic Role of Political Institutions: Market-Preserving Federalism and Economic Development, The." JL Econ. \& Org. 11 (1995): 1.

[47] World Bank Group, and Multilateral Investment Guarantee Agency. 2010 World Investment and Political Risk. World Bank Publications, 2011.

[48] World Bank Group, and Multilateral Investment Guarantee Agency. 2012 World Investment and Political Risk. World Bank Publications, 2013.

\section{Appendix A}

\section{Country sample, 1990-2011}

Algeria; Lithuania; Argentina; Malaysia; Azerbaijan; Mauritius; Belarus; Mexico; Botswana; Namibia; Brazil; Panama; Bulgaria; Peru; Chile; Romania; Colombia; Russian; Federation; Costa Rica; South Africa; Dominican Republic; Thailand; Ecuador; Tunisia; Iran; Turkey; Jordan; Uruguay; Kazakhstan; Venezuela; Latvia

\section{Appendix B}

Table 1. definition of variables and data source

\begin{tabular}{|c|c|c|}
\hline Variable & Definition & Sources \\
\hline FDI & $\begin{array}{l}\text { Foreign direct investment per capita, } \\
\text { net inflows in current US dollar }\end{array}$ & UNCTAD (2012) \\
\hline inflr & $\begin{array}{l}\text { the annual growth rate of consumer } \\
\text { price index }\end{array}$ & WDI (2012) \\
\hline open & $\begin{array}{l}\text { the sum of exports and imports to } \\
\text { GDP }\end{array}$ & UNCTAD (2012) \\
\hline mark & $\begin{array}{l}\text { defined in log of GDP in constant } \\
2005\end{array}$ & UNCTAD (2012) \\
\hline ecost & $\begin{array}{l}\text { annual growth rate at constant } 2005 \\
\text { US dollar }\end{array}$ & UNCTAD (2012) \\
\hline
\end{tabular}


Table 2. Panel Unit Root Tests Results at level

\begin{tabular}{|c|c|c|c|c|c|c|}
\hline \multirow{3}{*}{$\begin{array}{c}\text { Variable } \\
\text { LFDI }\end{array}$} & \multicolumn{6}{|c|}{ Intercept } \\
\hline & \multirow{2}{*}{$\begin{array}{c}\text { LLC } \\
-4.035\end{array}$} & \multicolumn{2}{|c|}{ IPS } & ADF-Fisher & \multicolumn{2}{|l|}{ PP-Fisher } \\
\hline & & * & -1.976 & 82.756 & 112.93 & \\
\hline Lfree & 4.8512 & & -3.593 & 109.19 & 614.14 & * \\
\hline Lopen & -5.307 & * & -5.513 & 151.28 & 112.05 & * \\
\hline Linfr & -5.268 & $*$ & -4.689 & 123.82 & 464.58 & * \\
\hline Lmark & -1.045 & & 5.675 & 18.295 & 25.777 & \\
\hline \multirow[t]{3}{*}{ Lecost } & -7.090 & * & -7.970 & 179.82 & 269.85 & * \\
\hline & \multicolumn{6}{|c|}{ Intercept and Trend } \\
\hline & LLC & \multicolumn{2}{|l|}{ IPS } & ADF-Fisher & \multicolumn{2}{|l|}{ PP-Fisher } \\
\hline$L F D I$ & -3.059 & * & -2.672 & * $\quad 94.314$ & * $\quad 129.18$ & * \\
\hline Lfree & 11.38 & & -3.336 & 109.30 & * $\quad 777.65$ & $*$ \\
\hline Lopen & -5.630 & * & -4.311 & 129.80 & 98.33 & * \\
\hline Linfr & -4.628 & * & -3.280 & 98.608 & * $\quad 149.48$ & * \\
\hline Lmark & -2.274 & & -1.295 & 78.504 & 84.049 & \\
\hline Lecost & -5.152 & $*$ & -3.973 & 114.95 & 196.87 & * \\
\hline \multicolumn{7}{|c|}{$\begin{array}{l}* \text { significant at } 1 \% \text { - rejection of the null hypothesis denotes the panel } \\
\text { series does not have a unit root } \\
\text { the values in front of each variable are t-statistic } \\
\text { The maximum lag length selection based on automatic Schwarz } \\
\text { Information criterion }\end{array}$} \\
\hline
\end{tabular}

